\title{
Policy Coherence and Social Protection in Ethiopia: Ensuring No One Is Left Behind
}

\author{
Melisew Dejene Lemma ${ }^{1, *}$ and Logan Cochrane ${ }^{1,2}$ (D) \\ 1 Institute for Policy and Development Research, Hawassa University, Hawassa 1558, Ethiopia; \\ logan.cochrane@gmail.com \\ 2 Global and International Studies, Carleton University, Ottawa, ON K1S 5B6, Canada \\ * Correspondence: etetu1978@gmail.com
}

Received: 3 February 2019; Accepted: 5 March 2019; Published: 12 March 2019 updates

\begin{abstract}
Ethiopia has made a strong commitment to strengthen its social protection system. However, resource constraints pose significant challenges in seeking to meet the basic needs of all people. We employ a qualitative research design to identify issues of policy incoherence, within the social protection policy and in relation to other sectoral policies. Policy incoherence has high costs. Strengthening policy coherence is necessary to improve the utilization of limited resources and set a pathway through which the government can ensure no one is left behind. We also present examples of implementation coherence, which provide insight into viable means through which improved policy coherence might be pursued.
\end{abstract}

Keywords: Ethiopia; social protection; policies; SDGS; leaving no one behind

\section{Introduction}

The 2030 Sustainable Development Agenda aims to 'leave no one behind' and this resonates with the objectives of the National Social Protection Policy of Ethiopia, which strives to put poor and vulnerable citizens first' [1]. The 2030 Agenda of 'leave no one behind' goes beyond social protection policy and calls for an integrated approach among various policy instruments rather than silos of practice. Policy coherence is vital in order to maximize synergy among sectoral interventions that would otherwise be fragmented at times with trade-offs. The framework for 'understanding policy coherence for sustainable development' developed by the Organisation for Economic Co-operation and Development (OECD) [2] (p. 52) suggests that achieving the sustainable development goals (SDGs), which have 17 integrated goals with 169 targets, necessitates 'whole-of-government approaches, strengthened coordination, enhanced policy coherence, as well as a more effective mobilisation, use and allocation of all available resources- public, private, domestic and international'. However, ambitions are one thing, implementing them is another. Existing research in Ethiopia suggests that past investments, such as those in infrastructure development and service provision, have been highly unequal and often excluded those most vulnerable and marginalized [3,4]. Social protection policies are influenced by socio-political, institutional, economic and historical factors. Any assessment of social protection policies, therefore, ought to be done within context, if the analysis and any recommendations are to be relevant [5].

The assessment of social protection policies in Ethiopia are important not only because of the support they provide for the most vulnerable in society, but also because significant resources are being allocated to the interventions outlined therein. In 2017/18, the Ethiopian government allocated 9 billion ETB (approx. US\$ 325 million) for activities pertinent to achieving the SDGs, out of its 230 billion ETB annual national budget (nearly $4 \%$ [6]). While the commitment of the Government of Ethiopia is laudable, it has insufficient funding to meet the basic needs of all its people [7]. Ensuring that policies 
and interventions are functioning well, therefore, requires assessments that promote effective and efficient resource utilization.

One reason why comparisons between plans and practices are important is because a significant amount of social protection funding is provided by donors. In many cases, it is not only the implementation that is funded, but also the plans and policies; with donors commissioning consultants to draft manuals, program implementation plans and policies. For example, the Program Implementation Plan of the most recent revision of the largest component of social protection in Ethiopia, the Productive Safety Net Program (PSNP), was led by donor-hired foreign consultants. While these documents are well designed and carefully thought out, they may not reflect the ideas of government personnel or be implemented accordingly. Further, they may not be designed to align with, and support other sectoral policies. As Andrews [8] notes, governments are well aware that plans need to look a certain way to obtain funding, even if the function acts in a completely different manner. The result can be a lack of policy coherence.

In this paper we analyze the social protection policy and strategy of Ethiopia in relation to its implementation, with a focus on the internal policy coherence of interventions within the social protection policy as well as external policy coherence in relation to other sectoral policies. Following the assessment, we reflect on the implications of implementation coherence for ensuring that no one is left behind. In addition to assessing the national context, we present a case study of one region, the Southern Nations, Nationalities and Peoples' Regional State (SNNPRS), to explore specific questions related to implementation. Due to Ethiopia's federal governance structure, this approach also provides insight into the ways in which the federal policies and regional state policies function in relation to one another.

\section{Materials and Methods}

Policy coherence deals with the relation and continuance within and between policies. We employ qualitative research design for this study taking the Ethiopian social protection policy as a case. The approach we have taken to assess policy and its coherence is one of the four types of policy coherence outlined in existing policy frameworks [9], which is a focus on consistency within the policy itself [9]. In this regard, we have applied a content analysis approach for the documents as well as a comparative narrative analysis with regard to how the government documents relate to other sources regarding the narratives within the policies. This approach was utilized as it aligns with the objectives of the paper. Further studies may deepen studies on policy coherence by employing alternative approaches. Other types of evaluation include: coherence among all government policies, policy 'harmonisation' in relation to the synergy and coordination between inter-government agencies, and 'ensuring alignment of government's policies with those of outside government' [10] (p. 5). The framework we draw upon was developed in line with the SDGs, and this aligns with our framing of these questions in the context of the 2030 Agenda and 'leaving no one behind' [2].

This paper focuses upon analysing the coherence among policies, interventions and provisions within the social protection policy itself (especially that of the social protection policy ratified in 2014 and the social protection strategy that came into effect in 2016) and in relation to other sectoral polices.Our analytic frame of 'the internal consistency' - the relationship between issues within the social protection policy-is limited to 'consistency and harmonization' within the policy and its implementation. Reference to other policies is made only when there is a need for clarity. We concur with Maile [9] (p. 7), who argues that there is 'no single blue print towards policy coherence', however we acknowledge what the new framework advances is in line with the SDG agenda, from a sectoral approach to a broader governmental approach that cohere various actors around 'issues' [2]. An issue such as 'food security', for example, convenes every sector from agriculture to energy, water, environment and trade, to list some (see [2]). Social protection policy lends itself to the 'issues' approach as preventive, protective, promotive and transformative issues involve many cross-cutting and inter-sectoral and trans-sectoral interventions. 
There are two levels of analysis in this paper: national and a regional case study. For the national analysis, we rely primarily upon government documentation, from the Ministry of Labour and Social Affairs (MoLSA) and the Ministry of Finance and Economic Development in particular. The national analysis is also supported by individual interviews that were held with two senior staff (the Director of Social Security Development Directorate and the advisor to the Minister) of MoLSA and a Member of Parliament (MP) from the House of People's Representatives (HPR) and Chair of the Social Affairs Standing Committee. This MP was involved during the development of the current social protection policy and facilitated deliberations among legislatures before the policy was signed into legislation. For the regional case study in SNNPRS, we held focus group discussions with Food Security Task Force Committee (FSTFC) members both at woreda (district) and kebele (the lowest level of political administration) levels. We also interviewed 52 PSNP beneficiaries. Informal social protection mechanisms and other familial and individual level supports are not within the scope of this study and are therefore not addressed. The study's proposal was reviewed by the Institute of Policy and Development Research (IPDR), Hawassa University, and granted approval as part of the first author's doctoral studies. The consent of all the participants was obtained before undertaking the study.

\section{Results}

\subsection{Scale of the Challenges}

'Ethiopia does not have a comprehensive and integrated social protection system' Ministry of Labour and Social Affairs [11] (p. 7)

Given Ethiopia's large population, the scale of challenges is immense. Consider the old age pension: in 2012 it was estimated that 500,000 people aged sixty or older have public sector pensions, of an estimated 3.6 million in this age group [11]. This means less than $14 \%$ were covered by public sector pensions. As of the last national census, conducted in 2007, almost another one million people were living with disabilities [12]. These figures appear very low; Tirrussew [12] suggests the figure is eight million people, while a more recent study by the WHO [13] suggests it could be 14 million. Currently, people living with disabilities are without any form of consistent governmental support, although the adviser to the Minister of Labour and Social Affiars (MoLSA) said the Ministry is working towards establishing a social protection fund to serve this population (personal interview, September 2017). Unemployment and underemployment pose significant challenges, and those experiencing it are without support as well. Official figures suggest the urban unemployment rate is $18 \%$, but is $28 \%$ for people in the 20-24 age group. The 2007 census identified an estimated 3.8 million orphaned children [11]. A census is planned for 2019, however until that is completed and data becomes available, an update of the situation can be obtained from the 2016 Ethiopian Demographic and Health Survey, which suggested a $2 \%$ decrease in the percentage of orphaned children, from $9 \%$ to $7 \%$, between 2011 and 2016. ${ }^{1}$ As a result, any form of support scheme targeting the most vulnerable in society, were it to reach people in just these population groups, would require an immense increase of both scale and budget, which both of the senior officials at MoLSA (the Adviser to the Minister and the Director of Social Security Development Directorate) we interviewed saw as a serious challenge (personal interviews, September 2017). This is also confirmed in government planning documents, such as those published by the National Planning Commission, which recognizes that funding and financing is insufficient to meet the basic needs of the population.

In addition to those experiencing long-term or permanent challenges, significant segments of the population are vulnerable to seasonal and annual vulnerabilities, such as drought, that require the

1 However, this decline should be considered alongside population growth since 2007 as well as these are percentages of the population See [46], (p. 12). 
provision of emergency support [14]. Vulnerabilities of this nature require social protection support of a different modality. Though still dependent on international partners, Ethiopia's emergency response for drought-induced crises has improved significantly in recent years [4]. This view is also shared by the MP (Personal Interview, July 2017) and the two senior officials of MoLSA (Personal Interviews, September 2017). The 2016 El Niño-induced drought that left over 10 million people in need of food aid, for example, was responded to by the government with an allocation of US\$ 730 million, while the international community contributed another US\$ 985 million [15]. These initiatives were in addition to the Productive Safety Net Program, supporting 8 million people.

The Government of Ethiopia appears to be aware of the challenges it faces, as demonstrated by the initiatives and policies it has developed and the gaps that have been identified. The National Social Protection Policy outlines gaps of "weak budgetary allocation" including a lack of guidelines and action plans, disconnected initiatives, the lack of standards resulting programs not being implemented equitably, and limitations of coverage amongst others [11] (pp. 12-13). These are also all concerns shared by all the policy makers and the beneficiaries of the Productive Safety Net Program (PSNP) interviewed for this study. This research is aimed to provide an assessment to support evidence-based decision making and improve internal and external policy coherence, while recognizing the constraints the Government of Ethiopia faces.

\subsection{A History of Social Protection in Ethiopia}

According to the Government of Ethiopia, formal social protection began in Ethiopia in 1963 with the establishment of a civil servant pension scheme [11]. This initiative began during the Imperial regime, and acted as a pension for government employees, namely public servants, members of the military and personnel of the police force. The population served by this first initiative represented a small segment of society, but set in motion consideration of how the government can support the citizens of the country. The pension initiative was continued by the military regime (1974-1991) and stayed in effect until the promulgation of Proclamation 345 in 2003, which amended and consolidated the provisions [16], again in 2011 with Proclamation 714 [17] and then in 2015 with Proclamation 907 [18]. It is not our objective to outline the history of this particular scheme, rather it is to note that this first initiative has evolved significantly over time and that multiple governments have contributed to the evolving social protection landscape. It is also noteworthy that imperfect policies may, over time, develop into better and more comprehensive ones. Initiating policies, and thereby changing the expectations of citizen-state relations, may act as a mechanism for future change.

Stating that social protection began in 1963 is, however, a rather narrow view of the history of various mechanisms of what could be termed social protection policies or practices. As the civil servant pension scheme sought to offer benefit to those who had served the government, kings of the past had issued land in a similar form, which was rented out in a landlord type manner from which the allocated land provided income [19]. We do not suggest such practices were fair or just, but that Ethiopia has a much deeper experience, and thus an individual and institutional experience, of social protection. There is also a wealth of non-state and informal social protection practices, such as church-based or mosque-based services, Iddir (burial socieites) and Iqqub (informal savings groups) and other support groups. A detailed historical analysis of these informal systems is beyond our scope, what we wish to emphasize however is that Ethiopia has deep historical experiences of state and non-state forms of social protection. Thus, current social protection practices and policies are not new to individuals, institutions or the government. The policy makers we interviewed, however, suggested that the social protection prototypes were different from regime to regime. The two senior officials of MoLSA saw the initiative by the Imperial regime as one of a 'charity model' not motivated by a rights-based approach (personal interviews, September 2017). Undoubtedly, the social protection landscape has evolved since the Imperial period, as have ideas around the world about what constitutes adequate social protection, including the introduction of rights-based approaches. 
During the Imperial regime (up to 1974), the political system functioned in an exploitative manner, negatively affecting the economic interests of the most vulnerable, namely the rural residents and smallholders [20,21]. Those who experienced the Wollo and Tigray famines of the 1960s and 1970s were largely ignored by the government, until pressure mounted due to a significant loss of life. Attempts to institutionalize emergency support at that time were limited [20,22,23]. Wolde Mariam [20] argues that the tax imposed on the rural smallholder was inflexible and burdensome, forcing rural residents to pay levies even during time of disaster. The establishment of the Relief and Rehabilitation Commission (RRC) was the first, and last, attempt by the Imperial government to institutionalize relief operations through a public agency [22], although there was an ad hoc food insecurity committee prior to it [24,25]. The RRC, however, was "a seven man work force" during its establishment and its relief efforts were marred by infrastructural limitations (especially road, transportation and communication constraints) and other resource challenges [24] (p. 272).

During the military regime (1974-1991), 'hand-out' humanitarian aid evolved into food-for-work schemes. The move from food aid to the food-for-work approach, which was introduced in the 1970s, was premised on two aims: (1) explicitly it sought to contribute to the rehabilitation of the eroded natural resources, especially in northern Ethiopia [26] and (2) implicitly, there may have been apprehension on the side of politicians that 'hand out' provisions may de-motivate the public from working [27]. The military regime used the politics of famine, among other things, to justify its coup d'état and implement a host of controversial policies. However, it too was challenged by nationwide catastrophes, such as the famine in 1984/1985. The regime's engagement in protracted civil conflicts with insurgent groups in the northern and eastern parts of the country, as well as a war with Somalia, reduced the already limited resources being used for social protection purposes [21].

Apart from relief efforts, the military regime introduced resettlement and villagization as part of their disaster response strategy [27-29]. Large-scale resettlement was undertaken in response to a nationwide emergency in the context of the 1984/1985 famine. The effort initially aimed to resettle nearly 1.5 million people within a period of two years, the implementation of which, due to poor planning, resulted in the loss of tens of thousands of lives [22,25,29]. Resettlement was justified as an improvement from fragmented relief approaches. It claimed to address long-term vulnerabilities and foster self-sufficiency by tackling the root causes of famine [19]. According to Rahmato [29] (p. 6), the 'cornerstone of the resettlement policy is the view that large areas of the country, suitable for agriculture and human habitation (often described as fertile virgin lands) are currently un- or under-utilized, and thus settlement programmes on these lands offer a sure way of acquiring the maximum benefit with the minimum cost'. Resettlement also sought to forcibly settle pastoralist populations as their livelihoods were conceived as less productive and 'spontaneous' [29]. Pankhurst [19] also describes the resettlement policy as having ecological, economic and social goals. Ecologically, it aimed to minimize the population pressure on the eroded northern highlands of the country. On the economic front, resettlement was hoped to boost productivity by cultivating the under-utilized fertile areas in the southern and western parts of the country. In the social front, resettlement was hoped to give access to land to those who were landless, to bring pastoralists to a settled life, and "remove unwanted urban unemployed" [22] (p. 121). The resettlement initiatives that the military government implemented had the support of foreign countries, including Italy, the then Soviet Union, Canada and the German Democratic Republic [27] (p. 130) and at a later stage by organizations including Food and Agriculture Organization, FAO, United Nations Development Programme, UNDP and United Nations High Commission for Refugees, UNHCR [29] (p. 18).

The resettlement program is an antecedent to the villagization initiative, also first implemented by the military regime. This program attempted to bring scattered rural households together for the purpose of providing services $[28,29]$. The villagization campaign of the military government was the largest of its type in Africa, with an ambitious aim outlined in rural development policies [28]. The villagization program was also criticized as it was hastily implemented and done without adequate planning $[28,29]$. In the political realm, its critics also noted, villagization facilitated the government 
control of rural households by collectivizing agriculture and 'monopolizing rural trade' [28] (p. 136). The adviser to the Minster of MoLSA argued that the military government's interventions were neither well planned nor were they based on the consent of the public, which according to him doomed them to failure (personal interview, September 2017).

During the military government, these initiatives were codified constitutionally, presenting an evolution in government-citizen relations with regard to social protection services. The Constitution of the People's Democratic Republic of Ethiopia under Article 10(2) and 10(3) paved the way for the institutionalization of both resettlement and villagization programs. Article 10(2) stipulated that the 'state shall ensure that human settlement patterns correspond to the distribution of natural resources in order to create favorable conditions for development' [30] (p. 19). Article 10(3) stated that the 'state shall encourage the scattered rural population to form consolidated communities in order to free rural life from backwardness and enable the people to attain a better social life' [30] (p. 19). The 1987 PDRE constitution also promised to progressively cater for social services in the form of social assistance and social insurance under Articles 20, 21 and 22. Article 20(1) promised social services for the family; Article 21 provided basic service provisions for the general public in the form of health services, pensions and insurance; and, Article 22 had provisions for the disabled war veterans (or military personnel). Constitutional codification was an important shift in the history of Ethiopia's social protection system.

\subsection{Current Social Protection Structures}

The current Government of Ethiopia (1991-present) views social protection as a means to make other investments more effective, efficient and to support economic growth [1,11]. Social protection is not presented as a right of citizens, nor as an obligation of the state to its citizens. Even when the constitutional rights are referred to, it is prefaced with the condition of 'progressive realization of social and economic rights'; which rights would be progressively realized, for whom and why, is left unstated [11] (p. 1). Even the constitution is vague about rights and responsibilities: Article 41(5) prefaces support with the condition of 'within available means', Article 41(6) states the 'state shall pursue policies' (rather than protect rights of individuals), and Article 41(7) states 'to the extent the country's resources permit'. What is not clear is how the available means and resources are determined, amidst a range of pro-growth objectives, which policies will be pursued, and for whom. This aligns with the broader ideological foundations of the government, whereby citizens are recipients of government benevolence, which acts to protect the population based upon what it deems as vital, not as something that citizens can demand [31,32].The rights that one could theoretically demand include the international conventions and instruments that the Government of Ethiopia has ratified, such as those outlined in the Universal Declaration of Human Rights [33], the African Charter on Human and Peoples' Rights [34], Convention on the Rights of the Child [35], Convention on the Elimination of all forms of Discrimination Against Women [36], and the African Charter on Rights and Welfare of the Child [37]. This is constitutionally upheld in Article 13(2): 'The fundamental rights and freedoms specified in this Chapter shall be interpreted in a manner conforming to the principles of the Universal Declaration of Human Rights, International Covenants on Human Rights and International instruments adopted by Ethiopia' [38]. However, in practice there are few examples when non-state actors or individuals have been able to demand such rights be protected (for an example of this see [39]). Throughout the most recent decade, the government has heavily restricted CSO and NGO abilities to engage in rights-based activities [40], which has restricted the support for any demand of these types.

Like its predecessors, the current ruling coalition of the Ethiopian Peoples' Revolutionary Democratic Front (EPRDF) has also been challenged by recurrent drought-induced catastrophes. The 1998/1999, 2003, 2008, 2015, 2016 and 2017 droughts left tens of millions of people food insecure and in need of food aid. The disaster response strategy of the present government that came into effect in 1993 sanctioned hand-out type provisions for any able-bodied person [41]. The policy took a 
different shape in 1996, when the first policy that might be considered a formal social protection policy emerged, aspiring to create 'developmental', preventative and rehabilitative programs [42]. From this, specific policies, would be based, namely the National Plan of Action on Older Persons (2006-2015), National Plan of Action for Persons with Disabilities (2012-2021), and Private Organization Employees Pension (Social Security) Scheme (2011 to present). According to the MP we interviewed, the efforts of the current government to expand social security coverage to private organization employees is a positive step towards internal coherence. Her concern, however, was that contractual employees who get recruited for a limited period and those in the informal economy are not yet covered (personal interview, July 2017).

One of the policies, which emerged in 2002 [43], sought to support food-insecure households. The strategic document has four components. These include: (1) a 'direct food production intervention program', which aimed to implement various schemes in the agricultural sector with an aim to boost agricultural productivity; (2) resettlement that aimed to settle people, on a voluntary basis, in areas with 'unused arable land'; (3) an 'income diversification program' that aimed to promote income diversification through off-farm activities; and (4) an employment creation scheme offering credit access to poor households. The PSNP was later made part of the food security strategy [44]. The PSNP aimed to lead to 'a gradual shift away from a system dominated by emergency humanitarian aid to productive safety net system resources via multi-year framework' [45] (p.1). The PSNP was designed with a three-pronged approach [14]. The first is 'consumption smoothing' for the chronically poor rural households by availing food or cash transfers especially during the 'hunger season'. The second is 'protecting household assets' from depletion due to chronic food insecurity and hunger. The third is establishing community assets through a public works scheme. The PSNP would develop to be Africa's second largest safety net program, supporting 8 million people.

Since 2005, the PSNP has been implemented in relatively food insecure areas of the country (but not all). It has two major components: public works (food-for-work modality) and the direct support (direct transfer). The public works program covers those households with at least one able-bodied adult, where beneficiaries are required to participate in public works activities to enhance community assets (e.g., village roads, irrigation ponds). For this, they are given a cash or food transfer for a maximum of six months per year. The fourth manifestation of the program, PSNP IV, which is a five-year program like its former three phases, has incorporated a livelihood transfer component, where beneficiaries are entitled to conditional credit (they need to save before being eligible) to invest in livelihood improving activities of their choice. The second component of the program, the direct support component, supports those beneficiaries who are not able-bodied and who are given support unconditionally based on their status. In PSNP IV, the direct support beneficiaries receive transfers throughout the year (previously this was for a maximum of 6 months per year). Most of the PSNP beneficiaries interviewed in this study indicated inconsistent practices, especially in the payment system, including during PSNP IV (personal interviews, Konsorechaffa, Korangoge, June 2017; Alage, Sheyembe May 2017). The Omo Micro Financial Institution (OMFI) is a govenrment affiliated institution contracted to pay PSNP beneficiaries. It is indicated in all areas we held FGDs that the OMFI failed to deliver its responsibilites (FGDs: BorichaWoreda, KonsoreChaffa, Korangoge, ShashogoWoreda, Alage, Sheyembe). PSNP-Public Works modality beneficiaries we interviewed, uninanimously blamed the payment delay associated to the functionings of OMFI (Personal Interviews, Konsorechaffa, Korangoge, June 2018; Alage, Sheyembe May 2018). The worst delay witnessed by FGD participants was three months for Public Works (FGD KonsoreChaffa, June 2017) and five months for Direct Support beneficiaires (FGD Korangoge, July 2018). A related, recently launched initiative is the Urban Productive Safety Net Program (UPSNP), which aims to expand the coverage of the safety net to urban areas. The UPSNP has been operational in 8 cities since mid-2016 as a pilot project and expanded to additional cities in 2017. As with PSNP, the UPSNP is primarily supported by the World Bank. 
Other initiatives being piloted in some areas of the country include social cash transfer schemes (in Tigray and SNNPRS), weather insurance in Oromia region, community-based health insurance (in effect since 2011 in 13 woredas in Amhara, Oromia, SNNPR and Tigray regions), and school feeding programs that aim to minimize school dropout in food insecure households. Related to supporting the most vulnerable, the National Nutrition Program (NNP 2013-2015), aimed to achieve three specific goals, namely: (1) minimize stunting among children from 44\% in 2013 to 30\% in 2015, (2) reduce wasting among children from 9.7\% in 2013 to 3\% in 2015, and (3) minimize chronic under-nutrition among women from $27 \%$ to $13 \%$ in 2015 . As of 2016, these targets had not been met, with limited progress in reducing wasting among children [46].

\subsection{Formalization of Social Protection Policies}

A high-level conference organized by the National Planning Commission in September 2018 convened experts and ministers to discuss the challenge of a lack of coherence among development policies in Ethiopia. This issue was identified as a hurdle for ensuring the equitable distribution of benefits in the country. A paper presented by Dr. Yohannes Ayalew, head of the Ethiopian Development Institute and former chief economist and deputy governor of the National Bank of Ethiopia, emphasized policy inconsistency as a critical issue to be addressed (ETV 4 September 2018). The then National Planning Commission commissioner, Eyob Tekalign, stated that the national economy faced challenges in recent years due to inconsistent policies, providing an example of the inconsistency in export trade and agricultural productivity. The commissioner argued that policies for promoting agricultural productivity do not adhere to the country's aspirations (ETV 4 September 2018).

Ethiopia promulgated a comprehensive Social Protection Policy in 2014, after the draft document had been on the shelf since March 2012. In the National Social Protection Policy, four priority areas were identified: social safety net, livelihood and employment schemes, social insurance, and addressing inequalities of access to basic services [11]. The 2016 National Social Protection Strategy added a fifth focus area, namely to provide legal protection and support for citizens exposed to abuse, exploitation and violence [2]. The initiation of the social protection policy involved various government sectors and diverse non-state actors, anditseems the initiators had 'policy coherence' in mind. Key government sectors involved during the policy development included the Ministry of Agriculture and Natural Resources, Ministry of Urban Development, Ministry of Health, Ministry of Women, Youth and Children Affairs (now evolved into two Ministries) and the Justice sector. Non-state actors included donors and other international organizations, including UNICEF, the World Bank, the EU, ILO and United States Agency for International Development, USAID.

To achieve these aims, it is outlined that the Government of Ethiopia would allocate $2 \%-3 \%$ of GDP to social protection. The policy classifies social protection initiatives as: (1) protective, such as in response to emergency situations, (2) preventative, to reduce asset loss through support, (3) promotive, to build assets and capacity, and (4) transformative, as systemic changes, such as legal change to protect against violence and abuse [11]. The five focus areas present a range of initiatives across these categories, and some initiatives, such as the safety net, have objectives from all four categories [2]. Within the policy and strategy documents there is an inherent assumption that macro-economic growth will trickle down to support the most vulnerable; whether that be through gross domestic product, agricultural surplus and export, large-scale agricultural production, or industrial investment $[2,11]$. These align with the objectives of the Growth and Transformation Plan of Ethiopia, as the "themes of the Growth and Transformation Plan are the foundation on which the social protection policy rests" [11] (p. 4).

The National Social Protection Policy outlined initiatives that have been in operation, which the Minister of Labour and Social Affairs notes were 'characterized by limited geographical coverage, inadequate inter-sectoral linkages and coordination, weak institutional capacity and lack of clarity regarding accountability or delivering social protection outputs' [2] (p. 1). The initiatives cover a range of entry points, summarized in brief as: (1) public sector pension program, started in 1963, covering an 
estimated 1\% of Ethiopians; (2) Food Security Program, including the PSNP, ${ }^{2}$ the Household Asset Building Programme (HABP), ${ }^{3}$ Voluntary Resettlement Programme (VRP), ${ }^{4}$ and Complementary Community Investment Programme (CCIP), ${ }_{i}^{5}$ (3) provision of basic services, including education, healthcare and water; (4) National Nutrition Program (NNP), targeting malnourished children and pregnant or lactating mothers; ${ }^{6}(5)$ support for vulnerable children, offering a range of project- and time-specific initiatives; ${ }^{7}$ (6) health insurance; community-based health insurance is being scaled with an aim for universal access; (7) disaster risk management, which includes emergency relief; ${ }^{8}$ (8) support for persons with disabilities, namely through supportive services, ${ }^{9}$ (9) support for older persons, ${ }^{10}$ (10) urban housing, namely the building of condominiums in urban areas and thereby improving service provisions; ${ }^{11}$ (11) employment promotion, in the form of enabling greater foreign direct investment and the provision of technical and vocational training; and (12) community-based social support, which are informal support systems such as food gifting and remittances.

\section{Discussion}

The Government of Ethiopia, and more specifically a number of its ministries, have enacted a range of policies and initiatives that strengthen social protection in Ethiopia. Not all of the policies have been enacted, and a number of the initiatives have not been funded, however we do recognize these as positive steps. What this article focuses upon is the lack of alignment and coordination of these activities, and the resulting policy incoherence. In this section, we outline specific examples where policy incoherence has emerged, which are examples of areas that require addressing in order to improve utilization of resources, enhance the social protection system as a whole, and reduce the potential for negative outcomes.

\subsection{Policy Coherence in the Social Protection Context}

We are unable to assess all of the initiatives outlined in the social protection policy that have been outlined in this article, however, in order to provide insight into policy coherence and implementation challenges we present several examples. First, the PSNP is not operational in some regions; coverage does not include Gambella and, until last year, Benishangul-Gumuz (with Asosa town becoming part of the UPSNP). Further, within the regional states where PSNP is operational, it only covers woredas categorized as food insecure. Thus, from a design perspective, this poses concerns regarding the equitable geographical distribution of resources, as articulated by the Minister of Labour and Social Affairs [2] (p. 21). It is also problematic in that areas of the country included in the PSNP are not necessarily those most in need of it [4]. In addition to geographic distribution, there are questions about timing. FGD participants in one community, for example, pointed out that public works are scheduled from January through June in their community. This timing does not seem in coherence with a season that has seen poor experiences of food shortage, and instead part of the plowing season (June through August). This suggests a lack of policy coherence between government's mainstream development

2 The rural PSNP supports an estimated 8 million people and the urban PSNP pilot plans to reach 604,000 people, three quarters of resources in the urban PSNP pilot were directed to Addis Ababa, MoLSA, 2016.

The HABP has been replaced by the livelihood component of PNSP IV.

Between 2003 and 2011, 224,021 households were resettled, MoLSA, 2012.

The CCIP is project specific, with a focus on supporting community infrastructure, in selected areas.

MoLSA estimates the program reaches 2.9 million children, 2012.

Examples of projects under this initiative include the provision of shelter, food, school materials to orphans.

The scale of emergency relief of food and non-food items has ranged from 1-13 million per year, MoLSA, 2012.

The Ministry of Labour and Social Affairs says the "numbers of beneficiaries is minimal compared to the total number" of persons living with disabilities, MoLSA, 2012.

10 Initiatives for older persons were not budgeted as of 2012, and services largely not delivered, MoLSA, 2012.

11 Under the urban housing initiatives, activities done to stabilize food prices are also included, such as reducing taxes on grains and regulating grain experts. 
policies that need to handle long term development activities and other sectoral decisions, in this case the Ministry of Agriculture and Natural Resource.

A second example of internal incoherence in the social protection policy includes the government attempt of developing condominium houses and promoting investment by expropriating farmland and evicting farmers with minimal compensation. To a degree, urban expansion is unavoidable. However, the practice is disempowering some, for the benefit of others. Compensation for expropriated land is minimal, livelihoods are lost, and former inhabitants do not have the required skills to join the urban labor market $[47,48]$. This process effectively shifts persons of coverage from one scheme to another without addressing the root issue-in this case moving individuals from an initiative with funding (rural safety net and agricultural extension) to an initiative without funding (serving the un-employed and under-employed).

A third example of internal incoherence is that the government activities in pastoral areas, are seeking to settle pastoralists and lease land to investors (domestic and international). In the process, pastoralist livelihoods are disrupted as these leases of land prohibit seasonal migration. This initiative is supported with voluntary options for pastoralists to resettle, although given that their livelihoods have been made much less viable one might question the voluntary nature of these options. However, at the same time the government is working with its partners to improve pastoralists' livestock and rangeland management practices [49-52] (p.103). The result is resources being invested into a livelihood practice that is increasingly being made unviable by a different set of policy actions and objectives.

The agriculture sector provides a fourth example of insufficient internal coherence. The second Growth and Transformation Plan (GTP II) indicated, that the 'supply of improved seeds was only 1.514 million quintals, which accounted for about $42 \%$ of the target set for 2014/15' [53] (p. 25). As outlined in the GTP II, and in the agricultural extension policy, farmers are strongly encouraged to adopt improved seed varieties, and the government measures progress using adoption as a key indicator of success. However, this runs counter to enhancing and protecting the biological and genetic diversity of the nation [54]. The latter objective has been used to support some policy positions, such as the ban on genetically modified organisms. Research suggests $[4,55]$ that the promoted varieties are not always the most appropriate, when soil types, elevation and agro ecologies are considered. Berhanu and Poulton [56] observed a compromise in the agricultural extension policy for political advantage. It is not impossible for both of these objectives to work in tandem, however the current arrangement is that adoption of improved seed is done as a 'package' approach and farmers do not have the ability to select from the top-down distribution system. Local seed varieties and more suitable options are being maintained by farmers, but often in contestation with the existing agricultural extension program. One alternative is integrating the two by integrating bottom-up processes whereby farmers can play a more active role in selecting individual components from packages.

A fifth example of how policies within a sector may be internally inconsistent is in educational policy, considered one of the key services provided to the population. The language policy of the EPDRF government created opportunities for children to learn in their mother tongues, which has had positive impacts [39]. At the same time, however, providing largely monolingual education in the primary years has yielded complex results in the long-term, as students from areas where local languages are spoken in limited geographic areas face limitations of work opportunities in other areas of the country [57]. An external policy conflict this educational approach has with other sectors is the industrial policy, whereby the government is facilitating the construction of industrial parks in regional centers to provide, mostly low-skill, work opportunities in manufacturing. Yet, the rural dwellers who may only have obtained primary schooling may not have adequate linguistic skills to take advantage of these opportunities, due to the educational policy. This is particularly the case in the linguistically diverse south of Ethiopia.

Social protection initiatives do not exist in a vacuum. The social protection policy, plans and initiatives interact with other sectoral policies, plans and initiatives, sometimes in less than 
complementary ways. One example of inter-governmental incoherence is evident in the newly established industry parks in Ethiopia. The Chair of the Social Affairs Standing Committee of the House of People's Representative argues: 'Social security is not given sufficient attention by all concerned parties including the government. For example, the country is moving to industrialization [with the establishment of Industry Parks], which is great, but some of the industry parks which are operational have many limitations in terms of protecting the rights of their workers' (Personal Interview, July 2017). The MP recounts a recent visit to Hawassa Industrial Park in south Ethiopia and argues that the facilities for promoting foreign direct investment as well as export have been well done. The customs clearance is being done on the spot. Banks and other important facilities are offered in a single location. On the other hand, however, there are workers who have no proper social protection, specifically with regard to labor rights. Following that experience, the MP suggested 'Bipartite and Tripartite negotiations (between the employer and employees or between the employer, employees and the government) so as to promote employees' rights' lest the objectives of one sectoral policy conflict with the objectives of another, or in this instance require new social protection initiatives to address the vulnerabilities created by another sectoral policy (Personal Interview, July 2017).

The need for policy coherence was emphasized by the Director of Social Security Development Directorate (SSDD) at the Ministry of Labor and Social Affairs, who was involved in crafting the current social protection policy, stating: 'Working on improving the lives of people requires the involvement of various sectors as interventions by one sector could not fulfill the different needs of that person' (Personal Interview, September 2017). The SSDD Director explained that the complex nature of social protection, combined with the existence of various implementers and diverse development strategies, makes the policy crafting process as well as its implementation slow, also alluding to resource constraints. These limitations ought not to be used to justify inaction and/or on-going policy coherence, particularly as that result in inefficient resource utilization, which is already limited and insufficient. For instance, though the policy outlines universal provision of old age pension for those aged 70 and above, irrespective of their employment situation, there has been no scheme in place to achieve this as of September 2018, despite the policy being promulgated four years earlier. The adviser to the Minister of Labour and Social Affairs provides a resourcist argument in stating:

Universal coverage is not feasible at our economic level. If you give universal coverage for the elderly for instance, you limit the interest of others. Mauritius, for example, made pension coverage universal because its population is small; school feeding is universal in Brazil because their economy is relatively strong. We are a poor economy. A county should go with its potential. Otherwise it challenges equity, for there are many others not covered yet and there are basic service issues (like electricity, water, health provisions) the government has to prioritize. In the short-term the universal theory is unlikely but it would be gradually possible (personal interview, September 2017).

However, Dejene, Semela and Haug [58], based on the ILO's Social Protection Floor Calculator, argue that Ethiopia could achieve universal social protection coverage for the elderly, the orphaned and the disabled with a budget of just at 3.47\% of its GDP. This is not only feasible for the economy, but it also could be achieved without affecting other government priorities. The spending adds to the economy as the revenue circulates, with beneficiaries spending the money in the market, and positively impacts family members, such as improving child health, and thus contributes to other social protection objectives [59,60].

\subsection{Implementation Coherence Providing Pathways for Policy Coherence}

Thus far we have focused on examples of policy incoherence and the challenges arising from that. However, we are also cognizant of examples of implementation coherence, particularly at the local level, that provide a pathway for how we might better approach policy coherence, within the Ethiopian context. The implementation of the PSNP at woreda and kebele levels (the lowest political 
administrations in Ethiopia) from the regional case study area of SNNPRS provides insight into implementation coherence. Coordination involves food security task force committees drawn from key government sectors, including Agriculture and Natural Resources, Health, Food Security, Transport and Water (along with representatives of Women and the Youth). The task force acts through an ad hoc committee in a way that pools key stakeholders. The assumption for this arrangement is to improve coordination and to support the identification and design of public works activities. Watershed management activities, for example, require proper understanding of the terrain and need to comply with the administrative plan by the Agriculture and Natural Resources sector. Public works activities like village feeder-roads require the consent of the community and alignment with the plan of the transport sector. Developing community level water sources like ponds may require the involvement of water and natural resources sectors.

Public Works participants in SNNPRS were involved in building residences for health extension workers and schools. This practice could be expanded as village feeder roads could enable access to health centers and the market, among other services. In one of the communities in SNNPRS, health extension workers use the Public Works activities for briefing the community on basic health issues like hygiene and family planning, as was designed to occur in PSNP IV. In another community, public works participants were involved in seedling production, being trained by a resource worker from Agriculture and Natural Resources. Farmer training centers (FTCs) were used for training purposes. One participant mentioned that he has gained access to mango and avocado trees, which he did not have earlier (and was trained on seedling production and management). Another experience from participants we interviewed was associating the PSNP Public Works (PWs) activities with developing water harvest ponds, those skills were then used to create such ponds on their own properties. Unlike its precedent PSNP III that set a fixed time for PWs period to run from January through June having had what is called 3-6-9 approach (where beneficiaries receive transfers based on identified need for 3 month only, 6 month only and 9 month only) (FGD, Boricha District, KonsoreChaffa, Kebele), PSNP IV recognized flexible public works timing that suits specific contexts and a consistent approach (with a six month transfer for PWs participants and 12 month transfer for Direct Support beneficiaries). According to the change in PSNP IV, the timing is chosen with the view that Public Works activities should not overlap with the agricultural activities of the respective communities. However, this has yet to be implemented in the study communities in SNNPRS.

\section{Conclusions}

The Government of Ethiopia has shown commitment to improving social protection by formulating a comprehensive social protection policy. The comprehensive social protection policy with wide areas of intervention is commendable. Aspirations to achieve the SDG agenda of 'leaving no one behind' are however being constrained by a host of issues. This article highlights issues of policy incoherence, which results in the inefficient utilization of limited resources. The lack of policy coherence is evident within the social protection policy itself, what we term internal policy coherence, and in relation to other sectoral policies, what we term external policy coherence. This paper has provided examples of both of these, exemplifying the manifestations of current incoherence as well as the problems that result from them. Notably, the results include not only ineffective resource use, but also the creation of new needs for social protection initiatives and even the emergence of conflict. There are, therefore, multiple reasons why policy coherence should be given high priority.

Should the SDG agenda of 'leaving no one behind' be achieved in Ethiopia by 2030, or at least the policies and programs put in place to create the pathways for such an aim to be achieved, internal and external policy coherence must be strengthened. Current positive practice suggests that collaboration and coherence are feasible, as demonstrated by local level examples of implementation coherence. The lessons learned from implementation coherence provide valuable insight into the pathways through which policy coherence might be fostered, aligning with the SDG 'issues' approach where intergovernmental sectors and diverse stakeholders work together around issues of common concern. 
Author Contributions: M.D.L. collected field data under the supervision of L.C. drafted an outline which was revised and edited by L.C. drafted the introduction and methods and Logan reviewed and made technical and content editions. Both authors contributed to the analysis and the conclusion sections.

Funding: The first author won a competitive PhD research grant funded by NORHED-DEG project. at Hawassa University, Ethiopia.

Acknowledgments: We acknowledge the NORHED-DEG project at Hawassa University for funding this study.

Conflicts of Interest: The authors declare no conflict of interest.

\section{References}

1. Ministry of Labour and Social Affairs (MoLSA). National Social Protection Strategy of Ethiopia; Ministry of Labour and Social Affairs: Addis Ababa, Ethiopia, 2016.

2. OECD. Better Policies for Sustainable Development 2016: A New Framework for Policy Coherence; OECD Publishing: Paris, France, 2016. [CrossRef]

3. Cochrane, L.; Rao, N. Is the Push for Gender Sensitive Research Advancing the SDG Agenda of Leaving No One Behind? In Forum for Development Studies; Routledge: London, UK, 2018. [CrossRef]

4. Cochrane, L. Food Security \& Ethiopia: Past Practices, Present Problems, Proposed Options; University of Alberta Press: Edmonton, AB, Canada, 2019.

5. Reisman, D. Richard Titmuss: Welfare and Society, 2nd ed.; Palgrave: New York, NY, USA, 2001.

6. The Reporter. Budget Breakdown, 17 June 2017. Available online: https:/ /www.thereporterethiopia.com/ content/budget-breakdown (accessed on 10 December 2018).

7. National Planning Commission. Growth and Transformation Plan (GTP) of the Federal Democratic Republic of Ethiopia (2015/16-2019/20); NPC: Addis Ababa, Ethiopia, 2016.

8. Andrews, M. The Limits of Institutional Reform in Development: Changing Rules for Realistic Solutions; Cambridge University Press: Cambridge, UK, 2013.

9. Maile, S. Policy Coherence: Meanings, Concepts and Frameworks. In Education and Poverty Strategy Policies: Issues of Policy Coherence; Maile, S., Ed.; HSRC Press: Cape Town, South Africa, 2008; pp. 1-18.

10. OECD. Senior Forum on Development Effectiveness in Fragile States: Harmonization and Alignment in Fragile States; Draft Report; OECD: London, UK, 2004.

11. Ministry of Labour and Social Affairs (MoLSA). National Social Protection Policy of Ethiopia; Ministry of Labour and Social Affairs: Addis Ababa, Ethiopia, 2012.

12. Tirrussew, T. Disability in Ethiopia: Issues, Insights and Implications; Addis Ababa University Press: Addis Ababa, Ethiopia, 2005.

13. WHO. World Report on Disability; World Health Organization: Geneva, Switzerland, 2011.

14. Devereux, S.; Guenther, B. Agriculture and Social Protection in Ethiopia; Working Paper 8; Future Agricultures: Brighton, UK, 2009.

15. WHO. Ethiopia: Humanitarian Requirements Document; WHO: Geneva, Switzerland, 2017; Available online: http:/ / www.who.int/health-cluster/ countries/ethiopia/ethiopia-humanitarian-response-plan-2017.pdf (accessed on 25 November 2018).

16. Federal Democratic Republic of Ethiopia (FDRE). Public Servants Pension Proclamation, Proclamation No. 345/2003; Federal Democratic Republic of Ethiopia: Addis Ababa, Ethiopia, 2003.

17. Federal Democratic Republic of Ethiopia (FDRE). Public Servants Pension Proclamation, Proclamation No. 714/2011; Federal Democratic Republic of Ethiopia: Addis Ababa, Ethiopia, 2011.

18. Federal Democratic Republic of Ethiopia (FDRE). A Proclamation to Amend the Public Servants Pension Proclamation, Proclamation No. 907/2015; Federal Democratic Republic of Ethiopia: Addis Ababa, Ethiopia, 2015.

19. Pankhurst, R. State and Land in Ethiopian History; Institute of Ethiopian Studies: Addis Ababa, Ethiopia, 1966.

20. Mariam, M.W. Rural Vulnerability Famine in Ethiopia: 1958-1977; Vikas Publishing House in Association with Addis Ababa University: Delhi, India, 1984.

21. Diriba, G. Economy at Cross Roads: Famine and Food Security in Ethiopia; Care International: Addis Ababa, Ethiopia, 1995.

22. Giorgis, D.W. Red Tears: War Famine and Revolution in Ethiopia; The Red Sea Press: Trenton, NJ, USA, 1989. 
23. Kiros, F.G. Enough with Famines in Ethiopia: A Clarion Call; Commercial Printing Enterprise: Addis Ababa, Ethiopia, 2005.

24. Adugna, S. Dirikin Lemekwakwam Yetederegu enkiskasewoch (1966-1983). In Ke dih'inet Wede Limat: Ewiketin Letiwilid Mastelalef; Bekele, S., Ed.; Forum for Social Studies: Addis Ababa, Ethiopia, 2014; pp. 263-298, ISBN 978-99944-50-50-3.

25. Seifu, H.M. Yet'idifiya Zemenat: Rehabina Chenefer, Yetarik Mastawesha; Falkon Printing Press: Addis Ababa, Ethiopia, 2013.

26. Holt, J. Ethiopia: Food for work or food for relief. Food Policy 1983, 8, 187-201. [CrossRef]

27. Pankhurst, A. Resettlement: Policy and Practice. In Ethiopia: Rural Development Options; Pausewang, S., Cheru, F., Brune, S., Chole, E., Eds.; Zed Books Ltd.: London, UK, 1990; pp. 121-134.

28. Lirenso, A. Villagization: Policies and Prospects. In Ethiopia: Rural Development Options; Pausewang, S., Cheru, F., Brune, S., Chole, E., Eds.; Zed Books Ltd.: London, UK, 1990; pp. 135-143.

29. Rahmato, D. Resettlement in Ethiopia: The Tragedy of Population Relocation in the 1980s; Forum for Social Studies: Addis Ababa, Ethiopia, 2002.

30. People Democratic Republic of Ethiopia (PDRE). The Constitution of the People's Democratic Republic of Ethiopia: Negart Gazetta Year No.1; Proclamation No.1 of 1987; People Democratic Republic of Ethiopia: Addis Ababa, Ethiopia, 1987.

31. Dejene, M.; Cochrane, L. Ethiopia's Developmental State: A Building Stability Framework Assessment. Dev. Policy Rev. 2019. [CrossRef]

32. Lefort, R. The theory and practice of Meles Zenawi: A response to Alex de Waal. Afr. Aff. 2013, 112, 460-470. [CrossRef]

33. UN. Universal Declaration of Human Rights; League of Nations: Geneva, Switzerland, 1948.

34. OAU. The African Charter on Human and Peoples' Rights; The Organization of African Union: Addis Ababa, Ethiopia, 1981.

35. UN. Convention on the Rights of the Child; United Nations: Geneva, Switzerland, 1989.

36. UN. Convention on the Elimination of All Forms of Discrimination Against Women; United Nations: Geneva, Switzerland, 1995.

37. OAU. African Charter on Rights and Welfare of the Child; The Organization of African Union: Addis Ababa, Ethiopia, 1999.

38. Federal Democratic Republic of Ethiopia (FDRE). Constitution of the Federal Democratic Republic of Ethiopia; Federal Democratic Republic of Ethiopia: Addis Ababa, Ethiopia, 1995.

39. Cochrane, L.; Betel, B.B. Pathways of Legal Advocacy for Change: Ethiopian Women Lawyer's Association. In Forum for Development Studies; Routledge: London, UK, 2018. [CrossRef]

40. Amnesty International. Ethiopia: The 2009 Charities and Societies Proclamation as a Serious Obstacle to the Promotion and Protection of Human Rights in Ethiopia, Amnesty International's Written Statement to the 20th Session of the UN Human Rights Council, 6-18 June 2012; Amnesty International: London, UK, 2012; Available online: https://www.amnesty.org/download/Documents/16000/afr250072012en.pdf (accessed on 28 November 2018).

41. Humphrey, L. Food-For-Work in Ethiopia: Challenging the Scope of Project Evaluations; IDS Working Paper; Institute of Development Studies: Brighton, UK, 1999; Volume 81, pp. 1-38.

42. Ministry of Labour and Social Affairs (MoLSA). Developmental Social Welfare Policy of the Federal Democratic Republic of Ethiopia; Ministry of Labour and Social Affairs: Addis Ababa, Ethiopia, 1996.

43. Federal Democratic Republic of Ethiopia (FDRE). The Federal Democratic Republic of Ethiopia Food Security Strategy; Federal Democratic Republic of Ethiopia: Addis Ababa, Ethiopia, 2002.

44. Nigatu, W. Food security strategy and Productive Safety Net Program in Ethiopia. In Digest of Ethiopia's National Policies and Strategies and Programs; Assefa, T., Ed.; Forum for Social Studies: Addis Ababa, Ethiopia, 2010.

45. Devereux, S.; Sabates-Wheeler, R.; Tefera, M.; Taye, H. Ethiopia's Productive Safety Net Programme (PSNP): Trends in PSNP Transfers within Targeted Households; Institute of Development Studies and Indak International Pvt. L. C: Sussex, UK; Addis Ababa, Ethiopia, 2006.

46. CSA and ICF Ethiopia. Demographic and Health Survey 2016; CSA: Addis Ababa, Ethiopia; ICF: Rockville, MD, USA, 2016. 
47. Kinfu, E.; Bombeck, H.; Nigussie, A.; Wogayehu, F. The genesis of periurban Ethiopia: The case of Hawassa city. J. Land Rural Stud. 2018. [CrossRef]

48. Megento, T. Inner city housing and urban development-induced displacement: Impact on poor female-headed households in Arada sub city of Addis Ababa, Ethiopia. J. Sustain. Dev. Afr. 2013, 15, 131-141.

49. Botterli, A. Adapting to Climate Change through Villagization? The Context of Sendentary Vulnerability in Afar Region, Ethiopia. Master's Thesis, Norwegian University of Life Sciences, Oslo, Norway, 2015.

50. Haji, J.; Leggesse, B. Impact of sedentarization program on the livelihood and food security of Ethiopian pastoralists. J. Arid Environ. 2016, 136, 45-53. [CrossRef]

51. National Meteorological Agency (NMA). Climate Change National Adaptation Programme of Action (NAPA) of Ethiopia; National Meteorological Agency: Addis Ababa, Ethiopia, 2007.

52. Yonas, B.; Beyene, F.; Nigatu, L.; Angasa, A. Influence of resettlement on pastoral land use and local livelihoods in Southwestern Ethiopia. Trop. Subtrop. Agroecosyst. 2013, 16, 103-117.

53. Ministry of Finance and Economic Development (MoFED). Growth and Transformation Plan I (GTP I) (2010/11-2014/15); Ministry of Finance and Economic Development: Addis Ababa, Ethiopia, 2010.

54. Institute of Biodiversity Conservation (IBC). Council of Ministers Regulation to Provide for Access to Genetic Resources and Community Knowledge, and Community Rights; Council of Ministers Regulation No. 169/2009; IBC: Addis Ababa, Ethiopia, 2009.

55. Carlsson, F.; Köhlin, G.; Mekonnen, A.; Yesuf, M. Are Agricultural Extension Packages What Ethiopian Farmers Want? A Stated Preference Analysis; Working Paper in Economics; Göteborg University Department of Economics: Göteborg, Sweden, 2005; Volume 172, pp. 1-18.

56. Berhanu, K.; Poulton, C. The Political Economy of Agricultural Extension Policy in Ethiopia: Economic Growth and Political Control. Dev. Policy Rev. 2014, 32, 199-216. [CrossRef]

57. Alemu, D.S.; Tekleselassie, A. Instructional language policy in Ethiopia: Motivated by politics or the educational needs of children. Plan. Chang. 2006, 37, 151-168.

58. Dejene, M.; Semela, T.; Haug, R. The 'problem represented to be' in the Social Protection policy regimes of Ethiopia, forthcoming. J. Policy Stud. 2019, under review.

59. Case, A.; Menendez, A. Does money empower the elderly? Evidence from the Agincourt demographic surveillance site, South Africa. Scand. J. Public Health 2007, 35, 157-164. [CrossRef] [PubMed]

60. FAO. Local Economy-Wide Impact Evaluation (LEWIE) of Ethiopia's Social Cash Transfer Pilot Programme; FAO: Rome, Italy, 2014.

(c) 2019 by the authors. Licensee MDPI, Basel, Switzerland. This article is an open access article distributed under the terms and conditions of the Creative Commons Attribution (CC BY) license (http:/ / creativecommons.org/licenses/by/4.0/). 